\title{
Characteristic miR-24 Expression in Gastric Cancers among Atomic Bomb Survivors
}

\author{
Yutaka Naito $^{a}$ Naohide Oue $^{a}$ Trang T.B. Phama ${ }^{a}$ Manabu Yamamoto \\ Megumu Fujihara $^{b}$ Teruyoshi Ishida ${ }^{c}$ Shoichiro Mukai ${ }^{a}$ Kazuhiro Sentani $^{a}$ \\ Naoya Sakamoto ${ }^{a}$ Eisuke Hidad Hiroki Sasaki ${ }^{\text {f }}$ Wataru Yasui ${ }^{a}$ \\ a Department of Molecular Pathology, Hiroshima University Institute of Biomedical and Health Sciences, \\ Departments of ${ }^{b}$ Pathology and ' Surgery, Hiroshima Red Cross Hospital and Atomic-Bomb Survivors Hospital, \\ and ${ }^{d}$ Center for Integrated Medical Research, Hiroshima University Hospital, Hiroshima, ${ }^{\text {eDepartment of }}$ \\ Gastroenterological Surgery, National Kyushu Cancer Center, Fukuoka, and ${ }^{\mathrm{f}}$ Department of Translational Oncology, \\ National Cancer Center Research Institute, Tokyo, Japan
}

\section{Key Words}

Gastric cancer - Radiation carcinogenesis - Atomic bomb · microRNA $\cdot \operatorname{miR}-24$

\begin{abstract}
Objective: To elucidate the mechanism of radiation-induced cancers, we analyzed the expression profiles of microRNAs extracted from formalin-fixed paraffin-embedded (FFPE) gastric cancer (GC) tissue samples from atomic bomb survivors. Methods: The expression levels of miR-21, miR-24, miR34a, miR-106a, miR-143, and miR-145 were measured by quantitative reverse transcription polymerase chain reaction (qRT-PCR). Results: The expression of microRNAs was measured by qRT-PCR in a Hiroshima University Hospital cohort comprising 32 patients in the high-dose-exposed group and 18 patients in the low-dose-exposed group who developed GC after the bombing. The GC cases showing high expression of miR-24, miR-143, and miR-145 were more frequently found in the high-dose-exposed group than in the low-dose-exposed group. We next performed qRT-PCR of miR-24, miR-143, and miR-145 in a cohort from the Hiroshima Red Cross Hospital and Atomic-Bomb Survivors Hospital
\end{abstract}

comprising 122 patients in the high-dose-exposed group and 48 patients in the low-dose-exposed group who developed GC after the bombing. High expressions of miR-24 and miR-143 were more frequently found in the high-dose-exposed group than in the low-dose-exposed group. Multivariate analysis demonstrated that only high expression of miR24 was an independent predictor for the exposure status. Conclusion: These results suggest that the measurement of miR-24 expression from FFPE samples is useful to identify radiation-associated GC.

(c) 2015 S. Karger AG, Basel

\section{Introduction}

Gastric cancer (GC) is the fourth most common malignancy worldwide, with approximately 870,000 new cases occurring each year (World Health Organization). The effect of radiation on GC development has been estimated on the basis of the Life Span Study (LSS), in which both mortality and incidence were used as end points. The excess relative risks per gray (Gy) were 1.20 for mortality [1] and 1.32 for incidence [2]. Cancer develops as a

\section{KARGER 125}

(c) 2015 S. Karger AG, Base

$1015-2008 / 15 / 0822-0068 \$ 39.50 / 0$

E-Mail karger@karger.com

www.karger.com/pat 
result of multiple genetic and epigenetic alterations [3]. Although several genetic alterations, including mutations in TP53 and BRAF, have been reported in several cancers from atomic bomb survivors [4-6], little is known about the changes in gene expression in radiation-associated GC. We previously showed that versican and osteonectin are expressed at much lower levels in tumor-associated stroma of atomic-bomb-exposed patients than in nonatomic-bomb-exposed patients [7]. However, little is known about changes in gene expression in radiationassociated GC.

MicroRNAs are 18- to 25-nucleotide, noncoding RNA molecules that regulate the translation of many genes [8]. Previous studies have shown that the expression levels of microRNAs are altered in most types of human cancers [9-11]. However, the expression of microRNA has not been investigated in atomic bomb survivors.

Biomarkers measured by RNA-based techniques require freshly frozen tissues. However, formalin-fixed paraffin-embedded (FFPE) tissue samples have been collected through decades of routine histopathologic examination and are the most widely available materials in clinical use. Unfortunately, formaldehyde-containing fixatives cause cross-linkage between nucleic acids and proteins, making the subsequent extraction and quantification of RNA challenging [12]. A major obstacle to the RNA expression analysis of FFPE tissues has been the uncertainty about whether gene expression analyses from routinely archived tissues accurately reflect the expression before fixation, and this is likely due to high fragmentation [13]. Because fragmentation does not cause further loss of quality when naturally occurring small RNAs are targeted, microRNAs are more ideal for the analysis of RNA extracted from FFPE samples.

In the present study, we aimed to identify potential molecular markers for radiation-associated GC by analyzing the expression profiles of microRNAs from FFPE GC tissue samples from atomic bomb survivors.

\section{Material and Methods}

\section{Tissue Samples}

In a retrospective study design, we used archival FFPE tissues from 239 patients who had undergone surgical excision of GC. The patients were treated at the Hiroshima University Hospital (HUH; Hiroshima, Japan) or at the Hiroshima Red Cross Hospital and Atomic-Bomb Survivors Hospital (HRCHABSH; Hiroshima, Japan).

An initial test cohort of 19 GC samples was used for TaqMan MicroRNA Array (Applied Biosystems, Austin, Tex., USA) analysis. All 19 patients were atomic bomb survivors in Hiroshima and were treated at the HUH. The second cohort $(n=50)$ was also an $\mathrm{HUH}$ cohort and was used as a validation cohort for quantitative reverse transcription polymerase chain reaction (qRT-PCR). All 50 patients were atomic bomb survivors in Hiroshima and were treated at the HUH. The initial test cohort of 19 GC patients and the second cohort of 50 GC patients were LSS cohort members, and atomic bomb radiation doses were estimated with the DS02 system [14]. They were further classified into 2 groups according to the levels of exposed radiation dose received: the high-dose-exposed group ( $\geq 5 \mathrm{mGy}$ ) and the low-dose-exposed group ( $<5 \mathrm{mGy}$ ).

The third cohort $(n=170)$ was the HRCHABSH cohort, which was used as a validation cohort for qRT-PCR. All 170 patients were atomic bomb survivors in Hiroshima and were treated at the HRCHABSH. Because these patients were not LSS cohort members, the atomic bomb radiation doses were not estimated. The HRCHABSH cohort patients included directly exposed patients and those not present in Hiroshima city at the time of bombing but who entered the city soon after the bombing (within 2 weeks). They were likewise classified into a high-dose-exposed group (directly exposed patients, exposure distance from the hypocenter of $\leq 4 \mathrm{~km}$ ) and a low-dose-exposed group (patients not present in Hiroshima city at the time of bombing but who entered the region $\leq 4 \mathrm{~km}$ from the hypocenter within 2 weeks after the explosion).

Tumor staging was performed according to the TNM classification system [15]. Histologic classification of GC was carried out according to the Lauren classification system [16].

\section{Ethical Considerations}

This study was approved by the Ethics Committee for Human Genome Research of Hiroshima University (Hiroshima, Japan).

\section{RNA Extraction from FFPE Samples}

The FFPE samples were sectioned $(10 \mu \mathrm{m})$, deparaffinized, and stained with hematoxylin and eosin to ensure that the sectioned block contained tumor cells. The tumor areas in the adjacent sections were marked under a light microscope. The tumor areas were macrodissected with sterile disposable scalpels and subjected to RNA isolation using the Recover AllTM Total Nucleic Acid Isolation kit (Ambion, Austin, Tex., USA), according to the manufacturer's instructions. Total RNA was quantified using the NanoDrop ND-1000 spectrometer (NanoDrop, Wilmington, Del., USA), and both optical density 260/280 and 260/230 ratios were used for quality control.

\section{TaqMan MicroRNA Array Analysis and qRT-PCR}

MicroRNA expression profiling was carried out with the TaqMan Array Human MicroRNA A Card v2.0 (Applied Biosystems) using the 7900 HT-Fast Real-Time PCR System (Applied Biosystems). The TaqMan Array Human MicroRNA A Card v2.0 is designed with 384 unique assays of human microRNAs. The microRNAs were amplified after specific reverse transcription and preamplification using Megaplex Assay Performance (Megaplex RT Primer Pools and Megaplex PreAmp Pools, Applied Biosystems) according to the manufacturer's instructions.

The expression levels of $m i R-21, m i R-24, m i R-34 a, m i R-106 a$, $m i R-143, m i R-145$, and RNU6B were measured using TaqMan MicroRNA Assays (Applied Biosystems). The cDNA was synthesized using microRNA-specific primers and a TaqMan MicroRNA Reverse Transcription kit (Applied Biosystems) according to the manufacturer's instructions. Briefly, 40 ng of RNA were reverse 
Table 1. Six microRNAs with higher expression in GCs from the high-dose-exposed group than those from the low-dose-exposed group

\begin{tabular}{llll}
\hline Name & Exposure status & mRNA expression & p value \\
\hline$m i R-21$ & High-dose exposed & $1.81(0.21-13.01)$ & 0.0437 \\
& Low-dose exposed & $0.11(0.01-11.39)$ & \\
\hline$m i R-24$ & High-dose exposed & $5.68(1.52-10.56)$ & 0.0194 \\
& Low-dose exposed & $1.35(0.03-6.97)$ & \\
\hline$m i R-34 a$ & High-dose exposed & $0.83(0.26-4.95)$ & 0.0258 \\
& Low-dose exposed & $0.11(0.01-6.33)$ & \\
\hline$m i R-106 a$ & High-dose exposed & $5.71(0.78-10.43)$ & 0.0437 \\
& Low-dose exposed & $0.56(0.02-8.51)$ & \\
\hline$m i R-143$ & High-dose exposed & $6.71(0.17-33.07)$ & 0.0437 \\
& Low-dose exposed & $0.20(0.01-9.77)$ & \\
\hline$m i R-145$ & High-dose exposed & $44.258(0.76-78.26)$ & 0.0339 \\
& Low-dose exposed & $1.10(0.02-202.77)$ & \\
\hline & & &
\end{tabular}

Values represent medians (ranges) unless otherwise stated. The $p$ values were assessed using the Mann-Whitney $U$ test. transcribed in a $20-\mu \mathrm{l}$ reaction with gene-specific RT probes. $\mathrm{qRT}$ PCR was performed using the 7900 HT-Fast Real-Time PCR System (Applied Biosystems). RNU6B was used as an endogenous normalization control. The relative target microRNA expression levels were calculated by the formula $2^{-\Delta \Delta \mathrm{CT}}$, where $\Delta \Delta \mathrm{CT}=\Delta \mathrm{CT}$ target microRNA $-\Delta$ CT RNU6B, and a $\geq 32$ CT value was interpreted as an amplification too low to quantify.

\section{In situ Hybridization}

The biotin 3 -labeled locked nucleic acid-incorporated microRNA probe ( $m i R$-CURY LNA detection probe, Exiqon, Woburn, Mass., USA) was used for the visualization of $m i R-24$. Scrambled probes were incubated as negative controls (Exiqon). The FFPE samples were sectioned, deparaffinized, and rehydrated. Sample slides were treated with proteinase K (Dako Cytomation, Carpinteria, Calif., USA) for $20 \mathrm{~min}$. A 20 -nM probe was hybridized with the $1 \times$ Enzo in situ hybridization buffer (Exiqon). The sample slides were heated to $50^{\circ} \mathrm{C}$ for $5 \mathrm{~min}$ and incubated at $37^{\circ} \mathrm{C}$ for $14 \mathrm{~h}$. Immunological detection was performed using the Dako GenPointTM Tyramide Signal Amplification System for Biotinlabeled Probes (Dako Cytomation). The sections were then exposed to a streptavidin-peroxidase reaction system and developed with DAB.

\section{Statistical Methods}

The differences in microRNA expression levels between 2 samples were tested by the Mann-Whitney $U$ test for individual genes. Univariate and multivariate logistic regression analysis was carried out to assess the relation among clinicopathologic characteristics, expression levels of microRNAs, and radiation exposure status. A $p$ value of $<0.05$ was considered statistically significant.
Table 2. Clinicopathologic characteristics of the patients by radiation exposure status in the HUH cohort

\begin{tabular}{llll}
\hline Variables & $\begin{array}{l}\text { High-dose- } \\
\text { exposed group } \\
(\mathrm{n}=32)\end{array}$ & $\begin{array}{l}\text { Low-dose- } \\
\text { exposed group } \\
(\mathrm{n}=18)\end{array}$ & p value \\
\hline $\begin{array}{l}\text { Median radiation } \\
\quad \text { dose, mGy }\end{array}$ & $72(5-2,601)$ & $0(0-4)$ & \\
$\begin{array}{l}\text { Sex } \\
\quad \text { Male }\end{array}$ & 17 & 10 & 0.8685 \\
$\quad$ Female & 15 & 8 & \\
$\begin{array}{l}\text { Age at diagnosis, years } \\
\quad \leq 65\end{array}$ & 6 & 2 & 0.4794 \\
$\quad 265$ & & 16 & \\
$\quad \begin{array}{l}\text { Tumor stage } \\
\quad \text { Stage I/II }\end{array}$ & 17 & 12 & 0.3517 \\
$\quad$ Stage III/IV & 15 & 6 & \\
$\begin{array}{l}\text { Lauren classification } \\
\quad \text { Intestinal }\end{array}$ & 16 & 14 & 0.0742 \\
$\quad$ Diffuse & 16 & 4 & \\
\hline
\end{tabular}

Values represent numbers (ranges) unless otherwise stated. The $\mathrm{p}$ values were assessed using Fisher's exact test.

\section{Results}

\section{MicroRNA Expression Profile}

To identify potential molecular markers for radiationassociated GC, we analyzed the microRNA expression profiles of the initial test cohort of 19 GC samples using the TaqMan MicroRNA Array. Among the 19 GC tissue samples, 5 samples were included in the high-dose-exposed patient group $(1,062,314,192,113$, and $102 \mathrm{mGy})$, and 14 samples were in the low-dose-exposed patient group $(<5 \mathrm{mGy})$. To determine whether there is a microRNA expression profile characteristic to exposed patients, we compared the expression levels of individual microRNAs between high-dose-exposed and low-doseexposed patient groups. The expression levels of $m i R-21$, $m i R-24, m i R-34 a, m i R-106 a, m i R-143$, and $m i R-145$ were significantly higher in GC from high-dose-exposed patients than in GC from low-dose-exposed patients (table 1). No microRNA showed a lower expression in GC from high-dose-exposed patient group than in GC from low-dose-exposed patient group.

Expression of miR-21, miR-24, miR-34a, miR-106a, $m i R-143$, and $m i R-145$ in the HUH Cohort

To validate the high expression of $m i R-21, m i R-24$, $m i R-34 a, m i R-106 a, m i R-143$, and $m i R-145$ in the high- 
Table 3. Univariate and multivariate Cox logistic analysis of $m i R-24$ expression and clinicopathologic characteristics in the HUH cohort

\begin{tabular}{|c|c|c|c|c|}
\hline \multirow[t]{2}{*}{ Characteristics } & \multicolumn{2}{|l|}{ Univariate analysis } & \multicolumn{2}{|l|}{ Multivariate analysis } \\
\hline & odds ratio $(95 \% \mathrm{CI})$ & $\mathrm{p}$ value & odds ratio $(95 \% \mathrm{CI})$ & $\mathrm{p}$ value \\
\hline \multicolumn{5}{|l|}{ Sex } \\
\hline Male & 1 (ref.) & \multirow[t]{2}{*}{0.4099} & 1 (ref.) & \multirow{2}{*}{0.3567} \\
\hline Female & $1.66(0.49-5.61)$ & & $1.85(0.49-7.26)$ & \\
\hline \multicolumn{5}{|l|}{ Age at diagnosis, years } \\
\hline$\leq 65$ & 1 (ref.) & \multirow[t]{2}{*}{0.6448} & 1 (ref.) & \multirow[t]{2}{*}{0.8091} \\
\hline$>65$ & $0.67(0.12-3.75)$ & & $0.77(0.09-6.41)$ & \\
\hline \multicolumn{5}{|l|}{ Tumor stage } \\
\hline Stage I/II & 1 (ref.) & \multirow{2}{*}{0.2943} & 1 (ref.) & \multirow[t]{2}{*}{0.7705} \\
\hline Stage III/IV & $1.96(0.56-6.85)$ & & $1.28(0.25-6.67)$ & \\
\hline \multicolumn{5}{|l|}{ Lauren classification } \\
\hline Intestinal & 1 (ref.) & \multirow{2}{*}{0.1443} & 1 (ref.) & \multirow[t]{2}{*}{0.4880} \\
\hline Diffuse & $2.67(0.71-10.00)$ & & $1.80(0.34-9.43)$ & \\
\hline \multicolumn{5}{|l|}{ Exposure status } \\
\hline High-dose group & 1 (ref.) & \multirow[t]{2}{*}{0.0100} & 1 (ref.) & \multirow[t]{2}{*}{0.0262} \\
\hline Low-dose group & $0.18(0.05-0.66)$ & & $0.21(0.05-0.83)$ & \\
\hline
\end{tabular}

dose-exposed patient group, the second cohort was analyzed. The second cohort $(\mathrm{n}=50)$ was the HUH cohort and was used as a validation cohort for qRT-PCR. All 50 patients were atomic bomb survivors (LSS cohort members) in Hiroshima, and the cohort comprised 32 highdose-exposed and 18 low-dose-exposed patients who developed GC after the bombing. The patient characteristics including sex, age at diagnosis, tumor stage, and Lauren classification are summarized in table 2 . The clinicopathologic characteristics of the patients did not statistically differ between the high-dose-exposed and lowdose-exposed patient groups.

We performed qRT-PCR of $m i R-21, m i R-24, m i R-34 a$, $m i R-106 a, m i R-143$, and $m i R-145$ in the 50 cases and divided the cases into high-microRNA expression and lowmicroRNA expression cases. When low expression was classified according to the lowest tertile, the number of high-microRNA expression cases was 34 , and the number of low-microRNA expression cases was 16. We performed univariate and multivariate logistic regression analyses to determine which variables are independent markers for radiation exposure status (table 3; see online suppl. tables 1-5; for all online suppl. material, see www. karger.com/doi/10.1159/000398809). In the univariate analysis, high expression of $m i R-24, m i R-143$, and $m i R-$ 145 was correlated with exposure status; however, high expression of $m i R-21, m i R-34 a$, and $m i R-106 a$ was not correlated with exposure status. In the multivariate analysis, only high expression of $m i R-24$ was correlated with exposure status (table 3 ), and high expression of $m i R-143$ or $m i R-145$ was not correlated with exposure status (online suppl. tables 4,5 ).

Expression of miR-21, miR-24, miR-34a, miR-106a, miR-143, and miR-145 in the HRCHABSH Cohort

Univariate analysis in the HUH cohort revealed that GC cases showing high expression of $m i R-24, m i R-143$, and $m i R-145$ were more frequently found in the highdose-exposed group than in the low-dose-exposed group. To further validate the high expression of $m i R$ 24 , $m i R-143$, and $m i R-145$ in atomic bomb survivors, a third cohort was analyzed. The third cohort $(\mathrm{n}=170)$ was the HRCHABSH cohort, in which atomic bomb radiation doses were not estimated because these patients were not LSS cohort members. The patient characteristics are summarized in table 4 . The clinicopathologic characteristics of the patients did not statistically differ between the high-dose-exposed and low-dose-exposed groups.

We performed qRT-PCR of $m i R-24, m i R-143$, and $m i R-145$ in the HRCHABSH cohort. These 170 GC cases were divided into high-microRNA expression cases and low-microRNA expression cases. When low expression was classified according to the lowest tertile, the number of high-microRNA expression cases was 113, and the number of low-microRNA expression cases was 57 . We performed univariate and multivariate logistic regression analyses to determine which variables might be independent markers for radiation exposure status. In the univariate analysis, high expression of both $m i R-24$ (table 5) 
Table 4. Clinicopathologic characteristics of patients by radiation exposure status in the HRCHABSH cohort

\begin{tabular}{|c|c|c|c|}
\hline Variables & $\begin{array}{l}\text { High-dose-exposed } \\
\text { group } \\
(\mathrm{n}=122)\end{array}$ & $\begin{array}{l}\text { Low-dose-exposed } \\
\text { group } \\
(\mathrm{n}=48)\end{array}$ & $\mathrm{p}$ value \\
\hline $\begin{array}{l}\text { Median distance from } \\
\text { the hypocenter, } \mathrm{km}\end{array}$ & $2.1(0.1-4.1)$ & $\begin{array}{l}\text { Located far from the } \\
\text { hypocenter at the time of the } \\
\text { atomic bomb explosion and } \\
\text { entered the exposed area later }\end{array}$ & \\
\hline \multicolumn{4}{|c|}{ - } \\
\hline Male & 80 & 28 & 0.3773 \\
\hline Female & 42 & 20 & \\
\hline \multicolumn{4}{|l|}{ Age at diagnosis, years } \\
\hline$\leq 65$ & 30 & 7 & 0.1547 \\
\hline$>65$ & 92 & 41 & \\
\hline \multicolumn{4}{|l|}{ Tumor stage } \\
\hline Stage I/II & 79 & 29 & 0.5969 \\
\hline Stage III/IV & 43 & 19 & \\
\hline \multicolumn{4}{|l|}{ Lauren classification } \\
\hline Intestinal & 58 & 31 & 0.0602 \\
\hline Diffuse & 64 & 17 & \\
\hline
\end{tabular}

Values represent numbers (range) unless otherwise stated. The p values were assessed using Fisher's exact test.
Table 5. Univariate and multivariate Cox logistic analysis of $m i R-24$ expression and clinicopathologic characteristics in the HRCHABSH cohort

\begin{tabular}{|c|c|c|c|c|}
\hline \multirow[t]{2}{*}{ Characteristics } & \multicolumn{2}{|l|}{ Univariate analysis } & \multicolumn{2}{|l|}{ Multivariate analysis } \\
\hline & odds ratio $(95 \% \mathrm{CI})$ & $\mathrm{p}$ value & odds ratio $(95 \% \mathrm{CI})$ & $\mathrm{p}$ value \\
\hline \multicolumn{5}{|l|}{ Sex } \\
\hline Male & 1 (ref.) & \multirow[t]{2}{*}{0.9430} & 1 (ref.) & \multirow[t]{2}{*}{0.9742} \\
\hline Female & $0.97(0.50-1.89)$ & & $0.99(0.49-1.98)$ & \\
\hline \multicolumn{5}{|l|}{ Age at diagnosis, years } \\
\hline$\leq 65$ & 1 (ref.) & \multirow[t]{2}{*}{0.5308} & 1 (ref.) & \multirow[t]{2}{*}{0.3463} \\
\hline$>65$ & $1.27(0.60-2.72)$ & & $1.46(0.66-3.23)$ & \\
\hline \multicolumn{5}{|l|}{ Tumor stage } \\
\hline Stage I/II & 1 (ref.) & \multirow[t]{2}{*}{0.4558} & 1 (ref.) & \multirow[t]{2}{*}{0.5293} \\
\hline Stage III/IV & $0.78(0.40-1.50)$ & & $0.80(0.41-1.59)$ & \\
\hline \multicolumn{5}{|l|}{ Lauren classification } \\
\hline Intestinal & 1 (ref.) & \multirow[t]{2}{*}{0.7063} & 1 (ref.) & \multirow[t]{2}{*}{0.8647} \\
\hline Diffuse & $1.13(0.59-2.14)$ & & $1.06(0.54-2.08)$ & \\
\hline \multicolumn{5}{|l|}{ Exposure status } \\
\hline High-dose group & 1 (ref.) & \multirow[t]{2}{*}{0.0050} & 1 (ref.) & \multirow[t]{2}{*}{0.0042} \\
\hline Low-dose group & $0.37(0.19-0.74)$ & & $0.35(0.17-0.72)$ & \\
\hline
\end{tabular}

and miR-143 (online suppl. table 6) correlated with exposure status; however, high expression of miR-145 (online suppl. table 7) did not correlate with exposure status. In the multivariate analysis, only high expression of $m i R-24$ (table 5) was correlated with exposure status, and high expression of $m i R-143$ or $m i R-145$ (online suppl. tables 6 , 7) was not correlated with exposure status.

\section{Expression and Localization of $m i R-24$ in $G C$}

We found that high expression of $m i R-24$ was an independent marker for exposure status by multivariate analysis in both the HUH cohort and the HRCHABSH cohort. Because high expression of $m i R-24$ was analyzed by qRT-PCR analysis of bulk GC tissues, we next determined which cells expressed $m i R-24$ by in situ hybridization. We 

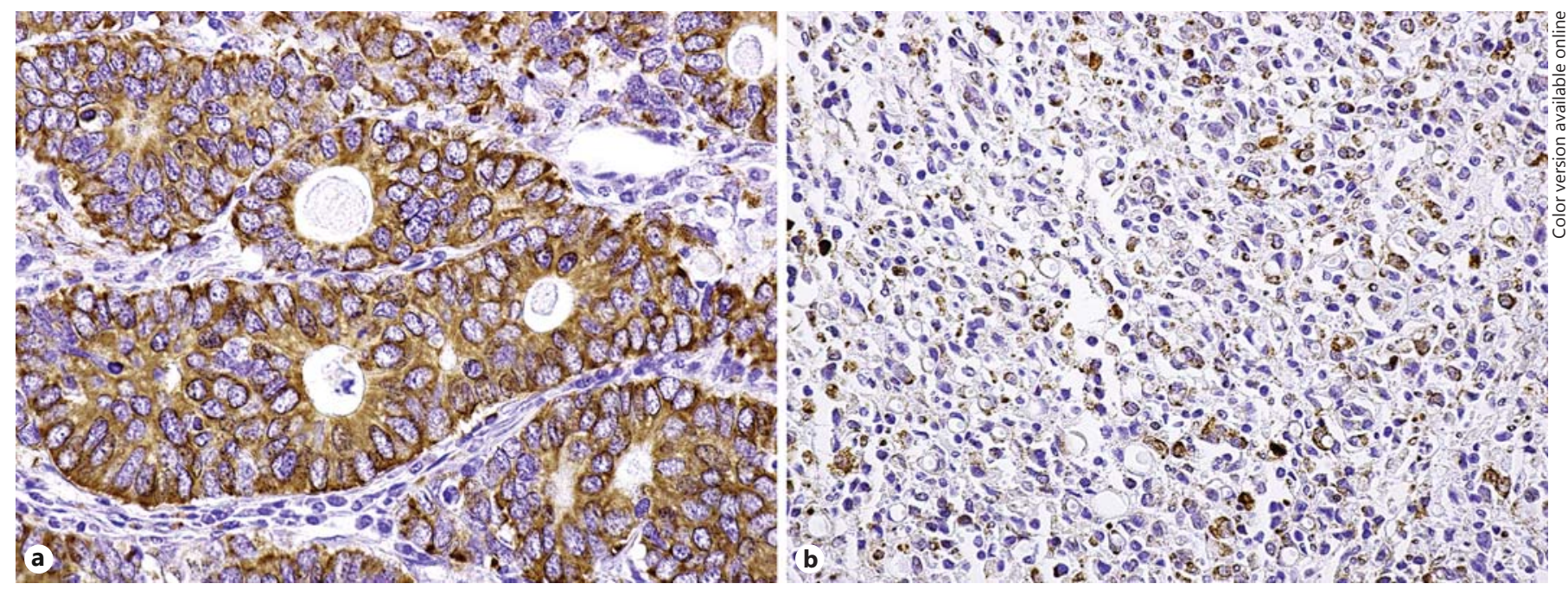

Fig. 1. In situ hybridization analysis of $m i R-24$ in GC tissue samples. a In situ hybridization analysis of $m i R-24$ in a GC case showing high $m i R-24$ expression. Original magnification, $\times 400$. b In situ hybridization analysis of $m i R-24$ in a GC case showing low $m i R-24$ expression. Original magnification, $\times 400$.

performed in situ hybridization in 5 GC cases showing high $m i R-24$ expression and in 5 GC cases showing low $m i R-24$ expression. Expression of $m i R-24$ was detected in GC cells from cases showing high $m i R-24$ expression (fig. 1a). In contrast, expression of $m i R-24$ was not detected in stromal cells, such as inflammatory cells and fibroblasts. In GC cases showing low miR-24 expression, few miR-24-positive GC cells were observed (fig. 1b).

\section{Discussion}

To identify potential molecular markers for radiationassociated GC and to better understand the development of radiation-associated GC, we here analyzed the microRNA expression profiles of GC from atomic bomb survivors. From the microRNA expression profiles of the initial test cohort by TaqMan MicroRNA Array, we found that the expression levels of $m i R-21, m i R-24, m i R-34 a$, $m i R-106 a, m i R-143$, and $m i R-145$ were significantly higher in GC from high-exposed patients than in GC from low-exposed patients. Among the examined microRNAs, only high expression of $m i R-24$ was an independent marker for exposure status by multivariate analysis in both the HUH cohort and the HRCHABSH cohort. GC cases showing high miR-24 expression were more frequently found in the high-dose-exposed patient group than in the low-dose-exposed patient group in both the

miR-24 Expression in Gastric Cancer of Atomic Bomb Survivors
HUH cohort and the HRCHABSH cohort. These results suggest that the measurement of the miR-24 expression from FFPE samples is useful to identify radiation-associated GC.

We found that GC showing high-miR-24 expression was frequently detected in high-dose-exposed patients. A previous study [17] showed that $m i R-24$ is downregulated in GC tissues compared with matched nontumor tissues and that ectopic expression of $m i R-24$ in GC cells suppressed cell proliferation, migration, and invasion in vitro as well as tumorigenicity in vivo. Furthermore, upregulation of $m i R-24$ in terminally differentiated cells has been demonstrated [18]. In contrast, in breast cancer, $m i R-24$ is overexpressed, and the ectopic expression of $m i R-24$ promotes breast cancer cell invasion and migration [19, 20]. Although downregulation of $m i R-24$ has been described in GC, the relationship with the radiation exposure history of patients has not been previously studied. Our study provides the first evidence of high $m i R-24$ expression levels in GC tissue samples from atomic bomb survivors.

MicroRNAs mediate sequence-specific posttranscriptional gene expression. One of the targets of $m i R-24$ is a histone H2AX, a key DNA double-strand break (DSB) repair protein [18]. DSBs are caused by the deleterious effects of ionizing radiation [21] and can induce chromosomal aberrations that cause cells to malfunction, resulting in cell death or tumorigenesis [22]. One of the earliest 
steps in the cellular response to DSBs is the phosphorylation of histone $\mathrm{H} 2 \mathrm{AX}$ at serine $139(\gamma \mathrm{H} 2 \mathrm{AX})$. The number of $\gamma \mathrm{H} 2 \mathrm{AX}$ foci has been correlated directly with the number of DSBs produced by ionizing radiation [23]. Therefore, the number of $\gamma \mathrm{H} 2 \mathrm{AX}$ foci is a significant marker for DSBs. Because in the high-dose-exposed patient group GC cases showing high miR-24 expression were frequently detected, the expression of H2AX could be downregulated, and chromosomal instability could frequently occur in GC. In fact, we previously showed that the number of $\gamma \mathrm{H} 2 \mathrm{AX}$ foci in high-dose-exposed patients is significantly higher than that in low-dose-exposed patients [24]. Analysis of chromosomal instability including gene amplification or deletion should be performed.

Previous reports showed that $m i R-24$ was downregulated in GC tissues compared with matched nontumor tissues. Ectopic expression of $m i R-24$ in GC cells suppressed cell proliferation, migration, and invasion in vitro as well as tumorigenicity in vivo [17]. The mechanisms of downregulation of $m i R-24$ in GC have not yet been completely investigated. At least, TGF- $\beta 1$ represses $m i R-24$ expression. Because TGF- $\beta 1$ is upregulated in GC [25], TGF- $\beta 1$ could suppress $m i R$ - 24 expression in low-doseexposed patients, and activation of TGF- $\beta 1$ signaling pathway may be absent in GC from the high-dose patient group. We previously showed that versican and osteonectin were expressed at much lower levels in the tumor-associated stroma of high-dose exposed patients than in low-dose-exposed patients, and both versican and osteonectin were targets of the TGF- $\beta 1$ signaling pathway [7, $26,27]$. Taken together, these data suggest that the TGF$\beta 1$ signaling pathway may not be activated in GC from high-dose-exposed patients. Other pathways that are activated in GC from high-dose patients should be elucidated.

In the HUH cohort and the HRCHABSH cohort, GC cases showing high $m i R-143$ expression were frequently found in the high-dose-exposed patient group. In contrast, multivariate analysis revealed that the expression of $m i R-143$ was not correlated with the exposure status. miR-143 has been shown to control smooth muscle cell phenotypes [28] and plays an important role in the pathogenesis of diffuse-type GC [29]. In the present study, in the HUH cohort and the HRCHABSH cohort, diffusetype GC was found more frequently in the high-dose-exposed patient group than in the low-dose-exposed patient group, although the difference was not statistically significant. Therefore, the correlation between $m i R-143$ expression and exposure status is attributable to the high frequency of diffuse-type GC in the high-dose-exposed patient group. In fact, high expression of $m i R-143$ was frequently found in diffuse-type GC in the HRCHABSH cohort.

In summary, we found frequent high expression of $m i R-24$ in GC in high-dose-exposed atomic bomb survivors. Because the present study is a retrospective study investigating gene expression patterns, without any functional assay, the study design does not allow elucidating any mechanisms of irradiation-induced cancers. Therefore, further investigation is required to examine the correlation between $m i R-24$ expression and radiation-induced cancer.

\section{Acknowledgments}

This work was carried out with the kind cooperation of the Research Center for Molecular Medicine, Faculty of Medicine, Hiroshima University. We thank the Analysis Center of Life Science, Hiroshima University, for the use of their facilities. This work was supported in part by Grants-in-Aid for Cancer Research from the Ministry of Education, Culture, Sciences, Sports, and Technology of Japan and in part by a Grant-in-Aid for the Third Comprehensive 10-Year Strategy for Cancer Control and for Cancer Research from the Ministry of Health, Labour and Welfare of Japan.

\section{References}

1 Preston DL, Shimizu Y, Pierce DA, Suyama A, Mabuchi K: Studies of mortality of atomic bomb survivors. Report 13. Solid cancer and noncancer disease mortality: 1950-1997. Radiat Res 2003;160:381-407.

- 2 Thompson DE, Mabuchi K, Ron E, Soda M, Tokunaga M, Ochikubo S, Sugimoto S, Ikeda T, Terasaki M, Izumi S, et al: Cancer incidence in atomic bomb survivors. Part II. Solid tumors, 1958-1987. Radiat Res 1994;137:S17-S67.
-3 Yasui W, Sentani K, Sakamoto N, Anami K, Naito Y, Oue N: Molecular pathology of gastric cancer: research and practice. Pathol Res Pract 2011;207:608-612.

4 Takeshima Y, Seyama T, Bennett WP, Akiyama M, Tokuoka S, Inai K, Mabuchi K, Land CE, Harris CC: p53 mutations in lung cancers from non-smoking atomic-bomb survivors. Lancet 1993;342:1520-1521. 
5 Takahashi K, Eguchi H, Arihiro K, Ito R, Koyama K, Soda M, Cologne J, Hayashi Y, Nakata Y, Nakachi K, Hamatani K: The presence of BRAF point mutation in adult papillary thyroid carcinomas from atomic bomb survivors correlates with radiation dose. $\mathrm{Mol}$ Carcinog 2007;46:242-248.

-6 Iwamoto KS, Mizuno T, Tokuoka S, Mabuchi K, Seyama T: Frequency of p53 mutations in hepatocellular carcinomas from atomic bomb survivors. J Natl Cancer Inst 1998;90:11671168.

7 Oue N, Sentani K, Sakamoto N, Motoshita J, Nishisaka T, Fukuhara T, Matsuura H, Sasaki H, Nakachi K, Yasui W: Characteristic gene expression in stromal cells of gastric cancers among atomic-bomb survivors. Int J Cancer 2009;124:1112-1121.

8 Huntzinger E, Izaurralde E: Gene silencing by microRNAs: contributions of translational repression and mRNA decay. Nat Rev Genet 2011;12:99-110.

-9 Lu J, Getz G, Miska EA, Alvarez-Saavedra E, Lamb J, Peck D, Sweet-Cordero A, Ebert BL, Mak RH, Ferrando AA, Downing JR, Jacks T, et al: MicroRNA expression profiles classify human cancers. Nature 2005;435:834-838.

10 Volinia S, Calin GA, Liu CG, Ambs S, Cimmino A, Petrocca F, Visone R, Iorio M, Roldo C, Ferracin M, Prueitt RL, Yanaihara N, et al: A microRNA expression signature of human solid tumors defines cancer gene targets. Proc Natl Acad Sci USA 2006;103:2257-2261.

-11 Ueda T, Volinia S, Okumura H, Shimizu M, Taccioli C, Rossi S, Alder H, Liu CG, Oue N, Yasui W, Yoshida K, Sasaki H, et al: Relation between microRNA expression and progression and prognosis of gastric cancer: a microRNA expression analysis. Lancet Oncol 2010;11:136-146

12 Srinivasan M, Sedmak D, Jewell S: Effect of fixatives and tissue processing on the content and integrity of nucleic acids. Am J Pathol 2002;161:1961-1971.
3 Specht K, Richter T, Müller U, Walch A, Werner M, Höfler H: Quantitative gene expression analysis in microdissected archival formalin-fixed and paraffin-embedded tumor tissue. Am J Pathol 2001;158:419-429.

14 Preston DL, Pierce DA, Shimizu Y, Cullings HM, Fujita S, Funamoto S, Kodama K: Effect of recent changes in atomic bomb survivor dosimetry on cancer mortality risk estimates. Radiat Res 2004;162:377-389.

15 Sobin LH, Compton CC: TNM seventh edition: what's new, what's changed: communication from the International Union Against Cancer and the American Joint Committee on Cancer. Cancer 2010;116:5336-5339.

16 Lauren P: The two histological main types of gastric carcinoma: diffuse and so-called intestinal-type carcinoma. An attempt at a histoclinical classification. Acta Pathol Microbiol Scand 1965;64:31-49.

17 Duan Y, Hu L, Liu B, Yu B, Li J, Yan M, Yu Y, Li C, Su L, Zhu Z, Xiang M, Liu B, et al: Tumor suppressor miR-24 restrains gastric cancer progression by downregulating RegIV. Mol Cancer 2014;13:127.

18 Lal A, Pan Y, Navarro F, Dykxhoorn DM, Moreau L, Meire E, Bentwich Z, Lieberman J, Chowdhury D: miR-24-mediated downregulation of H2AX suppresses DNA repair in terminally differentiated blood cells. Nat Struct Mol Biol 2009;16:492-498.

19 Sochor M, Basova P, Pesta M, Dusilkova N, Bartos J, Burda P, Pospisil V, Stopka T: Oncogenic MicroRNAs: miR-155, miR-19a, miR$181 \mathrm{~b}$, and miR-24 enable monitoring of early breast cancer in serum. BMC Cancer 2014;14: 448.

20 Du WW, Fang L, Li M, Yang X, Liang Y, Peng C, Qian W, O'Malley YQ, Askeland RW, Sugg SL, Qian J, Lin J, et al: MicroRNA miR-24 enhances tumor invasion and metastasis by targeting PTPN9 and PTPRF to promote EGF signaling. J Cell Sci 2013;126:1440-1453.

21 Hoeijmakers JH: Genome maintenance mechanisms for preventing cancer. Nature 2001; 411:366-374.
22 Van Gent DC, Hoeijmakers JH, Kanaar R: Chromosomal stability and the DNA doublestranded break connection. Nat Rev Genet 2001;2:196-206

-23 Sedelnikova OA, Rogakou EP, Panyutin IG, Bonner WM: Quantitative detection of (125) IdU-induced DNA double-strand breaks with gamma-H2AX antibody. Radiat Res 2002; 158:486-492.

24 Sentani K, Oue N, Sakamoto N, Nishisaka T, Fukuhara T, Matsuura H, Yasui W: Positive immunohistochemical staining of gamma$\mathrm{H} 2 \mathrm{AX}$ is associated with tumor progression in gastric cancers from radiation-exposed patients. Oncol Rep 2008;20:1131-1136.

$\longrightarrow 25$ Vagenas K, Spyropoulos C, Gavala V, Tsamandas AC: TGFbeta1, TGFbeta2, and TGFbeta 3 protein expression in gastric carcinomas: correlation with prognostics factors and patient survival. J Surg Res 2007;139:182-188.

26 Sakko AJ, Ricciardelli C, Mayne K, Tilley WD, Lebaron RG, Horsfall DJ: Versican accumulation in human prostatic fibroblast cultures is enhanced by prostate cancer cell-derived transforming growth factor beta 1 . Cancer Res 2001;61:926-930.

27 Reed MJ, Vernon RB, Abrass IB, Sage EH: TGF-beta 1 induces the expression of type I collagen and SPARC, and enhances contraction of collagen gels, by fibroblasts from young and aged donors. J Cell Physiol 1994; 158:169-179.

28 Hergenreider E, Heydt S, Tréguer K, Boettger T, Horrevoets AJ, Zeiher AM, Scheffer MP, Frangakis AS, Yin X, Mayr M, Braun T, Urbich $\mathrm{C}$, et al: Atheroprotective communication between endothelial cells and smooth muscle cells through miRNAs. Nat Cell Biol 2012;14:249-256.

29 Naito Y, Sakamoto N, Oue N, Yashiro M, Sentani K, Yanagihara K, Hirakawa K, Yasui W: MicroRNA-143 regulates collagen type III expression in stromal fibroblasts of scirrhous type gastric cancer. Cancer Sci 2014;105:228235. 